\title{
Development of the performance-potential survey for the quantitative placement of employees on the talent matrix
}

\author{
Alejandro González Cánovas ${ }^{1}$, Juan Fernández Millán ${ }^{1}$ (D), \\ Marina Fernández Navas² (iD, Victoria Sánchez Mas ${ }^{1}$ \\ ${ }^{1}$ Universidad de Granada (Spain) \\ ${ }^{2}$ Colegio Oficial de Psicólogos de Melilla (Spain) \\ agcanovas1124@gmail.com,fmillan1963@gmail.com,marinafn88@gmail.com,massanchesvictoria@gmail.com
}

Received September, 2018

Accepted January, 2020

\section{Abstract}

Purpose: The limited research conducted (scientific articles published in indexed journals) belies the interest that the talent matrix has in the business world. It is for this reason that the present work has been carried out, the aim of which is to create and validate a survey. The scores obtained reflect the positions of employees on the talent matrix, which will make it possible to place the evaluated subjects according to a quantitative criterion.

Design/methodology: The participants were 172 employees from different companies who were evaluated by middle management. $64.9 \%$ were men, and $35.1 \%$ were women. The research is framed within the "Instrumental studies" methodology, having used a non-probabilistic convenience sampling technique.

Findings: An 8-item survey has been developed on which the performance, potential and total scores allow us to quantitatively place the employees in the different boxes on the talent matrix. This serves to establish the human capital of the company and to facilitate staff replacements or promotions.

Practical implications: A validated instrument is provided to determine quickly and easily the talent of the human capital, on both an individual and a group level, which will permit decision-making for personnel management.

Social implications: The use of a quantitative instrument improves the perception of fairness on the part of businesses, and therefore improves the organizational climate.

Originality/value: The research is aimed and we believe would be of interest to Human Resource professionals, since it provides them with a tool that can be used to evaluate the talent of employees.

Keywords: Talent matrix, Performance, Potential

Jel Codes: $\mathrm{O} 15$ 


\section{To cite this article:}

González Cánovas, A., Fernández Millán, J., Fernández Navas, M., \& Sánchez Mas, V. (2020). Development of the performance-potential survey for the quantitative placement of employees on the talent matrix. Intangible Capital, 16(1), 1-13. https://doi.org/10.3926/ic.1362

\section{Introduction}

The management of a company's staff, and as part of this management, HR planning, is becoming a crucial task for the evolution and maintenance of organizations. This means that companies must find ways of attracting and keeping the right people for each position and having a priori "replacement" people who can be promoted (furthering their careers) as necessary for the organization and as satisfactory for the employee.

This recognition is what has been termed "human capital," understood as the productivity of workers in function of their training and job experience (Méndez, s.f.). Although for Sen (1998), it is more correct to speak of "human capacity," which does not limit the concept to its relationship with economic growth, the truth is that the term human capital has been imposed and is used to establish the manpower of a company, conceived of as the most valuable and basic resource, given that it is responsible for developing productivity (Martín, Segrero \& Perdomo, 2013; Mora Venegas, 2005).

From this perspective, personnel is no longer conceived of as a cost, but rather as a resource:"the main competitive resource" (Pereda \& Berrocal, 2011).

On its website, Work Meter (2014, March 27) states that "Talent management will be the challenge that Human Resource departments will need to face in 2015.Attracting candidates and, above all, retaining the best profiles, will be the most important challenges for companies over the next few months."

Personnel management requires techniques/procedures/tools that help define the possibilities available and the human capital needs that will arise in the future.

For this reason, the professional career plan (Mondy \& Noe, 2015; Siliceo, 2015) is a system that will allow us to know which positions might be replaced by which positions, i.e., it allows us to know the best person, with the required competences, at all times for a specific position, so that the company's objectives can be reached (Pereda \& Berrocal, 2011). One necessary step in this personnel management system is to create a professional path and itinerary plan (WIKI-EOI, 2012, May 10) that will help us know a priori staff member movements, both vertically and horizontally.

With this tool, we will know the possible rotations among positions; however, competence management is based on the fact that not all holders of the same position have the same level of competences. To accomplish this, a second management tool must allow us to differentiate among the talents of each of the employees. Knowing the distribution of the company's human capital will make it possible to select the right candidate for possible staffing needs. This talent management must be based on tools that facilitate the strategic planning and decisionmaking required by the company/organization (Cuesta, 2015).

The talent matrix is used for this task. Developed by Mckinsey (Figure 1), it was later improved in the late 1960s by General Electric. It consists of a double-entry table in which the employees are organized or distributed according to two factors: their performance and their potential. Three levels are established for each factor:

- Potential: low, medium and high.

- Performance: does not meet objectives, meets objectives or exceeds objectives.

Potential is understood as the capacity to acquire new knowledge and skills, generate innovative ideas and accept change, as well as having the predisposition and capacity to undertake new and different responsibilities (Porret, 
2014). Likewise, performance is made up by the behaviors and skills that the employee brings to a job position in order to fulfill responsibilities effectively and in a satisfactory manner (Porret, 2014).

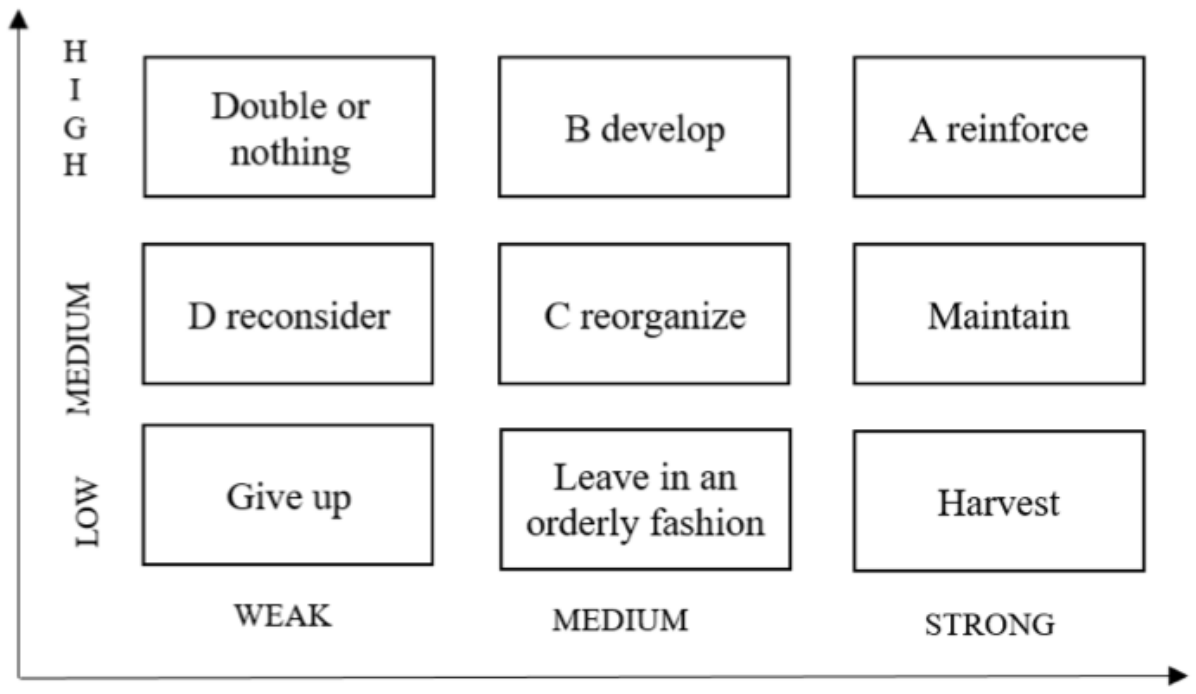

Figure 1. Mckinsey's talent matrix (Cuesta, 2015)

From the combination of the three levels of the two factors, we can obtain 9 boxes or categories that have been defined in different ways, all agreeing in their essential aspects. Cuesta (2015) identifies the following categories:

High Performance/High Potential: Future leaders/Stars

Medium Performance/High Potential: Growing/Emerging

High Performance/Medium Potential: Contributor

High Performance/Low Potential: Unclear/Latent

Medium Performance/Medium Potential: Core contributors/Traditional

High Performance/Low Potential: Trusted professionals/Workers

Medium Performance/Low Potential: Dilemma/Stagnant

Medium Performance/Low Potential: Effective employees/Blockers

Low Performance/Low Potential: Detractors

Once all the employees in a company are placed in this matrix and the number of workers in each box is converted into a percentage, the prospective conclusions can be reached and decisions made by virtue of the human capital that the company has.

Cuesta (2015) applied this system to a financial institution and found the following distribution (Table 1):

\begin{tabular}{|l|l|c|c|c|}
\hline \multirow{4}{*}{ Potential } & High & & $9 \%$ & $17 \%$ \\
\cline { 2 - 5 } & Medium & & $62 \%$ & $11 \%$ \\
\cline { 2 - 5 } & Low & $2 \%$ & & High \\
\cline { 2 - 5 } & & Low & Medium & \multicolumn{2}{|c|}{ Performance } \\
\cline { 2 - 5 } & \multicolumn{3}{|c|}{} \\
\hline
\end{tabular}

Table 1.Percentage of subjects distributed in the talent matrix boxes in the Cuesta study (2015) 
The placement of the 47 employees in the boxes is based on the scores obtained on the competence diagnostic tool, based on a Likert scale, using the Gauss bell-shaped curve to standardize the results, correct any possible deviations associated with trends in the evaluation and distribute the employees into the different boxes of the matrix.

The distribution of employees in the talent matrix will allow us, as previously stated, to make decisions in different personnel management areas, such as the design of the training offering, specifying the need for recruitment and personnel selection, succession planning, talent retention programs, etc.

The subjects can be distributed in the matrix by simply requesting the managers/leaders/observers to do so as they see fit, but it is more appropriate and objective to use other techniques to identify talent.

WIKI-EOI (2012, May 10) suggests different tools for this purpose: potential self-identification surveys, potential identification interviews, direct observation, simulations and professional tests and analyses of the person/job position fit.

Parallel to this, the use of methods that are standardized, recognized, and to the extent possible, objective will further benefit the company.

By definition, this use of objective methods and procedures agreed upon a priori will improve the perception of fairness on the part of the business (Martínez-Tur, Moliner, Ramos, Luque \& Gracia, 2014), a construct that at the same time is related to quality, work environment, wellbeing in the workplace and motivation.

Organizational fairness is understood as the perception that employees of a company have about the equity with which resources are assigned and distributed, the compensation and treatment by their superiors (Patlán, Flores, Martínez \& Hernández, 2014). In a very similar manner, Cropanzano, Rupp, Mohler and Schminke (2001) refer to this construct as the degree to which an element of the organization is perceived as just, according to a certain rule or standard. Concentrating on the elements (factors or dimensions) into which this concept is divided in the studies by Niehoff and Moorman (1993), we can differentiate among distributive, procedural and interactionrelated justice. By definition, we can state that the use of the talent matrix (and objective tools to evaluate employees) will positively affect the procedural justice, understood as the degree to which the procedures that are used for decision-making are perceived as fair (Thibaut \& Walker, 1975).

For Fernández-Losa (2002), if the company wishes to maximize the motivation of its employees, it must help them direct and manage their professional careers.

Research on the talent matrix is limited, as can be seen when searching for concepts such as "talent matrix" or "matriz del talento" in search engines such as Google Scholar and Google (general) (Table 2).

\begin{tabular}{|l|c|c|}
\hline Concept & Google Scholar & Google \\
\hline Matriz del Talento & $47^{*}$ & 44,300 \\
\hline Talent matrix & $107^{*}$ & 28,600 \\
\hline
\end{tabular}

$\left.{ }^{*}\right)$ Reference citations have been eliminated

Table 2. Results for the concepts "matriz del talento" and "talent matrix" in the following Internet search engines (October 2017)

The limited research conducted (scientific articles published in indexed journals) belies the interest that the talent matrix has in the business world. This is the reason for the present work, the aim of which is to create and validate a survey. The scores obtained reflect the positions of employees on the talent matrix, which will make it possible to place the evaluated subjects according to a quantitative criterion.

The initial hypotheses are that the performance, potential and overall scores obtained on the survey will correlate with those on the matrix (H1) and therefore, with the distribution into the boxes of the matrix (H2). 
The study must be complemented by others with a larger number of participants and considering other variables. In addition, as this study is the first attempt at a survey, it is necessary for future studies to conduct an exploratory and confirmatory factor analysis of the instrument.

One limitation found has been the scarce difference in the mean scores of the survey in relation to the boxes assigned on the matrix, and even that the hypotheses are not fulfilled in terms of the distribution of these scores among some of the boxes.

\section{Method}

\subsection{Participants}

The participants were 172 employees from different companies who were evaluated by middle management. $64.9 \%$ were men, and $35.1 \%$ were women. The age and seniority of the participants is shown in Table 3.In order to obtain the frequencies, the data were grouped for both age and seniority, in segments of 5 years (starting at age 20 and 1 year of seniority). See Figures 2 and 3.

\begin{tabular}{|l|r|r|}
\cline { 2 - 3 } \multicolumn{1}{c|}{} & \multicolumn{1}{c|}{ Age } & \multicolumn{2}{c|}{ Seniority } \\
\hline Mean & 46.93 & 9.95 \\
\hline Standard dev. & 12.09 & 3.78 \\
\hline Minimum & 25.00 & 1.00 \\
\hline Maximum & 60.00 & 15.00 \\
\hline
\end{tabular}

Table 3. Descriptive statistics of the participants in the study, according to age and seniority in their job positions

Age

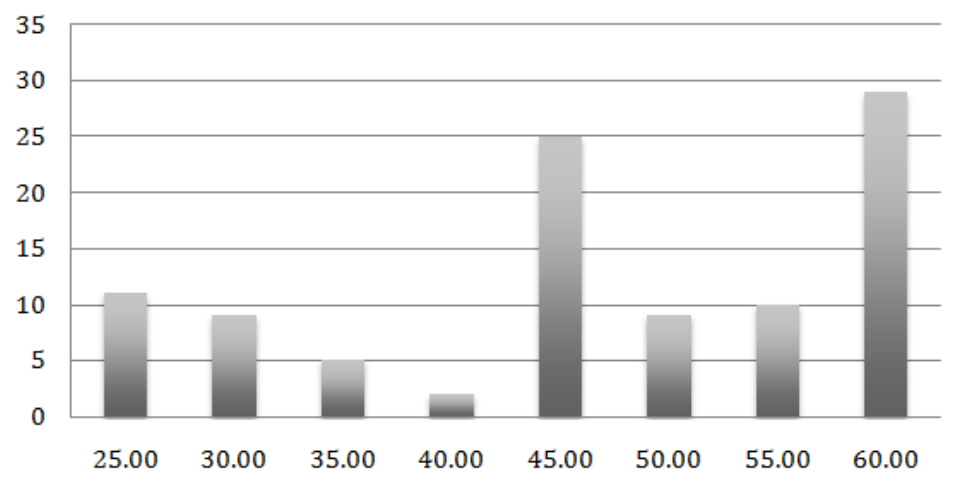

Figure 2. Percentage of subjects by age

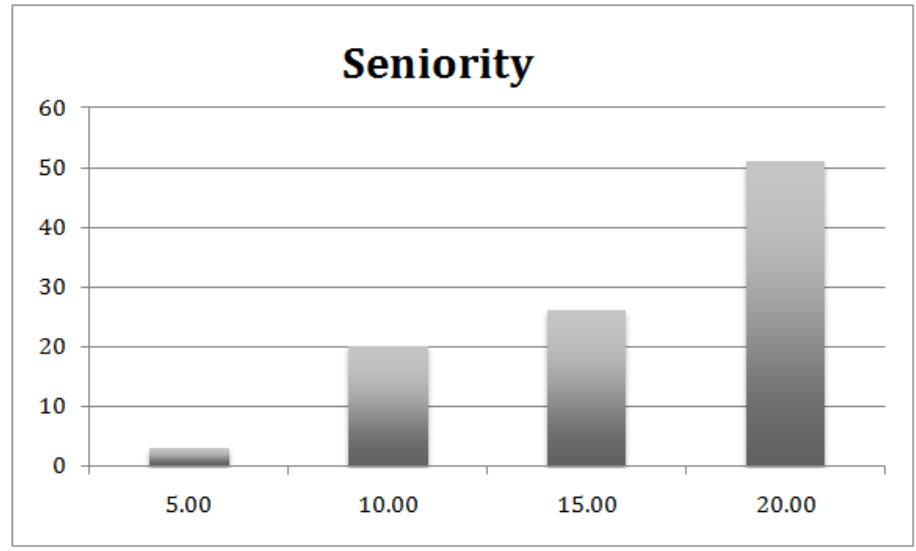

Figure 3. Percentage of subjects by seniority in the job position 


\subsubsection{Survey statistics}

The results show instrument reliability (Table 5) using Cronbach's $\alpha$ (.874), which is good, according to the criteria established by George and Mallery (2003).

\begin{tabular}{|r|r|rr|}
\hline $\begin{array}{c}\text { Cronbach's } \\
\text { alpha }\end{array}$ & $\begin{array}{c}\text { Cronbach's alpha, based on } \\
\text { standardized items }\end{array}$ & $\begin{array}{c}\text { Number of } \\
\text { items }\end{array}$ \\
\hline .874 & .879 & \\
\hline
\end{tabular}

Table 5. Survey reliability

No corrected total correlation of the items is 0 or less, and thus it was not necessary to eliminate any item.

According to Cronbach's alpha, the reliability of the sample (.874) would improve if we eliminate item 7 (.904).However, given the small number of items that make up the scale and the parity in those that evaluate performance and potential, the decision was made not to eliminate them (Table 6).

\begin{tabular}{|l|c|r|r|r|r|}
\cline { 2 - 5 } & $\begin{array}{c}\text { Mean of the } \\
\text { scale, if the } \\
\text { item is } \\
\text { eliminated }\end{array}$ & $\begin{array}{c}\text { Variance of } \\
\text { the scale, if } \\
\text { the item is } \\
\text { eliminated }\end{array}$ & $\begin{array}{c}\text { Corrected } \\
\text { total } \\
\text { correlation } \\
\text { of the items }\end{array}$ & $\begin{array}{c}\text { Squared } \\
\text { multiple } \\
\text { correlation }\end{array}$ & $\begin{array}{c}\text { Cronbach's } \\
\text { alpha, if } \\
\text { iteme } \\
\text { is } \\
\text { eliminated }\end{array}$ \\
\hline Item 1 & 16.8772 & 49.638 & .695 & .644 & .853 \\
\hline Item 2 & 16.6842 & 49.076 & .723 & .672 & .851 \\
\hline Item 3 & 16.6374 & 51.385 & .477 & .266 & .874 \\
\hline Item 4 & 17.3392 & 46.331 & .772 & .719 & .843 \\
\hline Item 5 & 17.4211 & 45.445 & .754 & .668 & .844 \\
\hline Item 6 & 17.6433 & 43.925 & .798 & .765 & .838 \\
\hline Item 7 & 16.7602 & 54.983 & .218 & .124 & .904 \\
\hline Item 8 & 17.5673 & 46.482 & .730 & .685 & .847 \\
\hline
\end{tabular}

Table 6. Total item statistics

\subsubsection{Correlations among the survey scores and the matrix}

The correlations that are of interest for this study are those that relate the same factors on the survey and on the matrix. As can be seen in Table 7, all three are significant at a level of 0.01.According to the criteria of both Hopkins, Marshall, Baterham and Hanin (2009) and Cohen (1988), the effect size (d) associated with the correlation ( $r$ ) would be large for all three variables.

\begin{tabular}{|c|c|c|c|c|c|}
\hline & & & \multicolumn{3}{|c|}{ Matrix } \\
\hline & & & Development & Potential & Total \\
\hline \multirow{9}{*}{ Survey } & \multirow{3}{*}{ Development } & $\begin{array}{l}\text { Pearson } \\
\text { correlation }\end{array}$ & $.679^{* *}$ & $.415^{* *}$ & $.688^{* *}$ \\
\hline & & Sig.(bilateral) & .000 & .000 & .000 \\
\hline & & $\mathbf{N}$ & 172 & 172 & 172 \\
\hline & \multirow{3}{*}{ Potential } & $\begin{array}{l}\text { Pearson } \\
\text { correlation }\end{array}$ & $.574^{* *}$ & $.505^{* *}$ & $.683^{* *}$ \\
\hline & & Sig.(bilateral) & .000 & .000 & .000 \\
\hline & & $\mathbf{N}$ & 172 & 172 & 172 \\
\hline & \multirow{3}{*}{ Total } & $\begin{array}{l}\text { Pearson } \\
\text { correlation }\end{array}$ & $.665^{* *}$ & $.490^{* *}$ & $.729^{* *}$ \\
\hline & & Sig.(bilateral) & .000 & .000 & .000 \\
\hline & & $\mathbf{N}$ & 172 & 172 & 172 \\
\hline
\end{tabular}

(**) The correlation is significant at the 0.01 level (bilateral).

Table 7. Correlations between the survey factors and the matrix 
With regard to the variables of gender, seniority and age, significant negative correlations (0.01) appear with a large effect size $(\mathrm{d}=1)$ between age and the three survey scores. There is also a significant negative correlation $(0.05)$ with a moderate effect size $(\mathrm{d}>0.6)$ between seniority in the job position and potential (Table 8$)$.

\begin{tabular}{|c|c|c|c|c|c|}
\hline & & & \multirow{3}{*}{\begin{tabular}{|l|} 
Age \\
$-.444^{* *}$ \\
\end{tabular}} & \multirow{3}{*}{$\begin{array}{r}\text { Seniority } \\
-.145\end{array}$} & \multirow{3}{*}{$\begin{array}{r}\text { Gender } \\
.176\end{array}$} \\
\hline & & & & & \\
\hline \multirow{9}{*}{ Survey } & \multirow[t]{3}{*}{ Performance } & Pearson correlation & & & \\
\hline & & Sig.(bilateral) & .001 & .286 & .191 \\
\hline & & $\mathbf{N}$ & 57 & 56 & 57 \\
\hline & \multirow[t]{3}{*}{ Potential } & Pearson correlation & $-.444^{* *}$ & $-.298^{* *}$ & .152 \\
\hline & & Sig.(bilateral) & .001 & .026 & .259 \\
\hline & & $\mathbf{N}$ & 57 & 56 & 57 \\
\hline & \multirow[t]{3}{*}{ Total } & Pearson correlation & $-.462^{* *}$ & -.231 & .170 \\
\hline & & Sig.(bilateral) & .000 & .087 & .205 \\
\hline & & $\mathbf{N}$ & 57 & 56 & 57 \\
\hline
\end{tabular}

$(* *)$ The correlation is significant at the 0.01 level (bilateral).

$\left.{ }^{*}\right)$ The correlation is significant at the 0.05 level (bilateral).

Table 8. Correlations between the survey factors and personal and work-related variables

Finally, as can be seen in Table 9, significant negative correlations (0.01) appear with a large effect size between the total scores obtained on the survey and the assigned box on the matrix.

\begin{tabular}{|c|c|c|c|}
\hline & & & Box \\
\hline \multirow{9}{*}{ Survey } & \multirow{3}{*}{ Performance } & Pearson correlation & $-.843^{* *}$ \\
\hline & & Sig.(bilateral) & .000 \\
\hline & & $\mathbf{N}$ & 57 \\
\hline & \multirow{3}{*}{ Potential } & Pearson correlation & $-.864^{* *}$ \\
\hline & & Sig.(bilateral) & .000 \\
\hline & & $\mathbf{N}$ & 57 \\
\hline & \multirow{3}{*}{ Total } & Pearson correlation & $-.887^{* *}$ \\
\hline & & Sig.(bilateral) & .000 \\
\hline & & $\mathbf{N}$ & 57 \\
\hline
\end{tabular}

Table 9. Correlations between the total scores obtained on the survey and the number of the matrix box assigned to the subject

\subsubsection{Means and standard deviations obtained on the survey of the subjects distributed in the assigned boxes}

Distribution of the participants (no. of subjects per box)

Table 10 shows the distribution of the 172 participants in the different matrix boxes. 


\begin{tabular}{|r|r|}
\hline \multicolumn{1}{|r|}{ Box } & \multicolumn{1}{|c|}{ N } \\
\hline 1 & 22 \\
\hline 2 & 10 \\
\hline 3 & 24 \\
\hline 4 & 4 \\
\hline 5 & 21 \\
\hline 6 & 33 \\
\hline 7 & 16 \\
\hline 8 & 27 \\
\hline 9 & 15 \\
\hline
\end{tabular}

Table 10. Number of subjects assigned in the different matrix boxes

Table 11 shows the mean scores and the standard deviations in performance obtained on the survey, according to the subject's classification on the matrix.

\begin{tabular}{|c|c|c|}
\hline $\mathbf{1 0 . 7 5}$ & $\mathbf{1 1 . 4 0}$ & $\mathbf{1 5 . 0 9}$ \\
$\mathbf{2 . 5 0}$ & $\mathbf{3 . 1 7}$ & $\mathbf{1 . 0 6}$ \\
\hline $\mathbf{9 . 6 3}$ & 9.00 & 13.25 \\
$\mathbf{2 . 9 8}$ & 3.76 & 1.87 \\
\hline $\mathbf{3 . 2 0}$ & 7.43 & 12.43 \\
$\mathbf{1 . 4 7}$ & 2.60 & 2.04 \\
\hline Low & Medium & High \\
\hline
\end{tabular}

Table 11. Means and standard deviations in the performance factor of the survey, according to the box assigned to the subject

If we accept our hypothesis that the performance score obtained on the survey correlates with that obtained on the matrix, and thus determines the box in which the subject must be placed, the scores must be centrifugally larger from box 9 on, particularly in the horizontal direction. Observing the table, it can be seen that this does occur, both horizontally (from 9 to 5 , from 8 to 3 and from 4 to 1 ), and diagonally (from 9 to 1 ), except between boxes 8 and 6 .

Table 12 shows the mean scores and the standard deviations in potential obtained on the survey, according to the subject's classification on the matrix.

\begin{tabular}{|l|r|r|r|}
\hline High & 10.75 & 10.20 & 14.41 \\
& 0.50 & 3.01 & 1.76 \\
\hline Medium & 6.66 & 8.27 & 11.21 \\
& 3.38 & 3.16 & 2.86 \\
\hline Low & 3.13 & 5.69 & 11.80 \\
& 2.26 & 2.77 & 2.68 \\
\hline
\end{tabular}

Table 12. Means and standard deviations in the potential factor of the survey, according to the box assigned to the subject

In the case of potential, the scores increase diagonally from box 9 to 11 and vertically from the bottom boxes (9, 7 and 5$)$ to the top ones (4,2 and 1), except between boxes 5 and 3 .

Table 13 shows the mean scores and the standard deviations in total scores obtained on the survey, according to the subject's classification on the matrix. 


\begin{tabular}{|l|c|c|c|}
\hline \multirow{2}{*}{ High } & 21.50 & 21.60 & 29.50 \\
& 3.00 & 5.76 & 2.24 \\
\hline \multirow{2}{*}{ Medium } & 16.29 & 17.27 & 24.46 \\
& 5.65 & 6.19 & 3.55 \\
\hline \multirow{2}{*}{ Low } & 6.33 & 13.12 & 24.24 \\
& 2.89 & 4.81 & 3.95 \\
\hline & Low & Medium & High \\
\hline
\end{tabular}

Table 13. Means and standard deviations in the total score of the survey, according to the box assigned to the subjects

In agreement with the hypotheses, the total scores increase diagonally, horizontally and vertically.

\section{Discussion and conclusions}

The results obtained in this study support the suitability of the use of the survey to evaluate talent, understood as the level of current performance and potential for improvement, of employees in an organization in a simple, quick and quantifiable manner. Once the scores for the two factors and the total are obtained, and knowing the mean scores for each box, the professional can "place" each subject on the matrix and convert the number of employees into percentages that will be used to determine the talent and future of the company in terms of its human capital.

The data on the reliability of the survey are sufficient to conclude that it is a statistically reliable instrument.

The correlations obtained between the survey scores and the matrix, in turn, confirm our hypothesis (H1) and allow us to conclude that the data obtained on the survey reflect the levels on the matrix.

The correlation (negative) found between age and the factors indicates that with age, the performance and potential decrease, which did not occur in relation to seniority in the job position. This is an aspect that requires further work to determine the reason why employees perform less and are less prepared with age. One possible explanation would be that the effect owes more to a generational culture than to age itself.

Finally, the mean scores found for each matrix box allow us to place the subject on the matrix, according to the scores obtained on the survey, albeit with some limitations.

The study has some limitations on both a methodological level (number of participants) and in terms of the results. Further work must be done with a larger number of participants and considering other variables. One limitation found has been the scarce difference in the mean scores of the survey in relation to the boxes assigned on the matrix, and even that the hypotheses are not fulfilled in terms of the distribution of these scores among some of the boxes. Furthermore, an important line of work emerges from the present study: to ensure that, by applying the matrix, it is possible to obtain the expected results with regards to the evolution of professionals. It is thus necessary to conduct a longitudinal analysis that confirms or refutes its utility over time.

In the field of organizational or work psychology, and more specifically, in Human Resources, a greater number of studies need to be conducted for the practical purpose of giving companies reliable systems to manage their staffs.

\section{Declaration of Conflicting Interests}

The authors declared no potential conflicts of interest with respect to the research, authorship, and/or publication of this article.

\section{Funding}

This research has been carried out thanks to the Faculty of Social and Law Sciences of Melilla and the Department of Social Psychology at the University of Granada. 


\section{References}

Ato, M., López, J., \& Benavente, A. (2013). Sistema de clasificación de los diseños de investigación en psicología. Anales de Psicologia, 29 (3), 1038-1059. https://doi.org/10.6018/analesps.29.3.178511

Cohen, J. (1988). Statistical Power Analysis for the Behavioral Sciences (2nd. Ed.). Lawrence Erlbaum Associates, Publishers. Retrieved from: http://www.utstat.toronto.edu/ brunner/oldclass/378f16/readings/CohenPower.pdf

Cropanzano, R., Rupp, D.E., Mohler, C.J., \& Schminke, M. (2001). Three roads to organizational justice. Research in Personnel and Human Resources Management, 20, 1-113. https://doi.org/10.1016/S0742-7301(01)20001-2

Cuesta, X.V. (2015). Proceso Gestión de talento en la Unidad Financiera del Grupo Industrial Graiman. Tesis Universidad del Azuay. Maestría en Recursos Humanos y Desarrollo Organizacional II

Fernández-Losa, N. (2002). El desarrollo profesional de los trabajadores como ventaja competitiva de las empresas. Cuadernos de Gestion, 2 (1). Retrieved from:

http://www.ehu.eus/cuadernosdegestion/documentos/214.pdf

George, D., \& Mallery, P. (2003). Spss for Windows step by step: A Simple Guide and Reference. 11.0 Update (4th ed.). Boston: Allyn \& Bacon.

Hopkins, W.G., Marshall, S.W., Baterham, A.M.., \& Hanin, J. (2009). Progressive statistics for studies in sports medicine and exercise science. Medicine \& Science in Sports \& Exercise, 41 (1), 3-12. Retrieved from: https://journals.lww.com/acsm-msse/Fulltext/2009/01000/Progressive Statistics for Studies in Sports.2.aspx

Martín, X., Segredo, A., \& Perdomo, I. (2013). Capital humano, gestión académica y desarrollo organizacional. Educación Médica Superior, 27(3), 288-295.

Martínez-Tur, V., Moliner, C., Ramos, J., Luque, O., \& Gracia, E. (2014). Calidad y bienestar en organizaciones de servicios: El papel del clima de servicio y la justicia organizacional. Papeles del Psicólogo, 35 (2), 99-106.

Méndez, J.C. (s.f.). La importancia del Capital Humano en las Organizaciones. Retrieved from: http://www.arearh.com/rrhh/capital humano.htm

Mondy, R., \& Noe, R. (2015). Administración de recursos humanos (11 ${ }^{\text {th }}$ ed.). México: Pearson Educación.

Mora Venegas, C. (2005). El Capital Humano en el comportamiento organizacional [monografía en Internet]. [citado 12 Sep 2012]. Available at: http://www.gestiopolis.com/canales5/rrhh/elhucompor.htm

Morales, P. (2008). Estadística aplicada a las Ciencias Sociales. Madrid: Universidad Pontificia de Comillas.

Niehoff, B.P., \& Moorman, R.H. (1993). Justice as a mediator of the relationship between methods of monitoring and organizational citizenship behavior. Academy of Management Journal, 36, 527-556. https://doi.org/10.2307/256591

Patlán, J., Flores, R., Martínez, E., \& Hernández, R. (2014). Validez y confiabilidad de la escala de justicia organizacional de Niehoff y Moorman en población mexicana. Contaduría y Administración, 59(2), 97-120.

Retrieved from: file:///C:/Users/Windows7/Downloads/58-58-1-PB.pdf https://doi.org/10.1016/S01861042(14)71256-2

Pereda, S., \& Berrocal, F. (2011). Dirección y gestión de recursos bumanos por competencias. Madrid: Ed. Universitaria Ramón Areces.

Pérez, O. (2014). Matriz de Administración de Talento Humano de las 9 Cajas. Retrieved on December 2nd from: http://blog.peoplenext.com.mx/matriz-de-administacion-de-talento-humano-de-las-9-cajas

Porret, M. (2014). Gestión de personas. Manual para la gestión del capital bumano en las organizaciones (6 ${ }^{\text {th }}$ ed.). Barcelona: Ed. ESIC.

Sen, A. (1998). Capital humano y capacidad humana. Cuadernos de Economia, 17(29), 67-72

Siliceo, A. (2015). Capacitación y desarrollo de personal ( $5^{\text {th }}$ ed). México: Editorial Limusa, S.A. 
Thibaut, J., \& Walker, L. (1975). Procedural justice: A psychological analysis. Hillsdale, NJ: Lawrence Erlbaum Associates, Inc.

WIKI-EOI, (2012). Diseño e implantación de un plan de desarrollo profesional en Recursos humanos. Retrieved on May $10^{\text {th }}$ from: http://www.eoi.es/wiki/index.php/Dise $\% \mathrm{C} 3 \% \mathrm{~B} 1 \mathrm{o}$ e implantaci $\% \mathrm{C} 3 \% \mathrm{~B} 3 \mathrm{n}$ de un plan de desarrollo profesional en Recursos humanos

WORK METER (2014). Gestión del talento mediante el uso de herramientas tecnológicas. Retrieved on March $27^{\text {th }}$ from: https://es.workmeter.com/blog/bid/339469/Gesti-n-del-talento-mediante-el-uso-de-herramientas-tecnolgicas

\section{Appendix A}

Performance-potential survey

Data of the evaluated employee:

Employee no. (assign a number to each evaluated employee)

\begin{tabular}{|c|c|c|}
\hline \multicolumn{3}{|c|}{ Put an X next to the response that corresponds to the evaluated employee } \\
\hline \multirow[t]{9}{*}{ Age } & \multicolumn{2}{|c|}{$<20$} \\
\hline & \multicolumn{2}{|c|}{$21-25$} \\
\hline & \multicolumn{2}{|c|}{$26-30$} \\
\hline & \multicolumn{2}{|c|}{$31-35$} \\
\hline & \multicolumn{2}{|c|}{$36-40$} \\
\hline & \multicolumn{2}{|c|}{$41-50$} \\
\hline & \multicolumn{2}{|c|}{$51-55$} \\
\hline & \multicolumn{2}{|c|}{$56-60$} \\
\hline & \multicolumn{2}{|c|}{+60} \\
\hline Gender & Male & Female \\
\hline \multirow[t]{4}{*}{ Years in the company (approx.) } & \multicolumn{2}{|c|}{ Less than 1 year } \\
\hline & \multicolumn{2}{|c|}{$1-5$ vears } \\
\hline & \multicolumn{2}{|c|}{$6-12$ years } \\
\hline & \multicolumn{2}{|c|}{ More than 10years } \\
\hline
\end{tabular}

Read the following items on the survey carefully and mark the box with an $\mathrm{X}$ that most closely matches the person being analyzed.

\begin{tabular}{|l|l|l|l|l|l|}
\hline Items & Never & Sometimes & Normally & $\begin{array}{c}\text { Almost } \\
\text { always }\end{array}$ & Always \\
\hline $\begin{array}{l}\text { 1. Completes his/her tasks or objectives on } \\
\text { time (daily, monthly, yearly, etc.). }\end{array}$ & & & & \\
\hline $\begin{array}{l}\text { 2. Is concerned about correctly performing the } \\
\text { functions of his/her position. }\end{array}$ & & & & & \\
\hline 3. Is punctual in coming to work. & & & & & \\
\hline $\begin{array}{l}\text { 4. Is capable of suggesting solutions to } \\
\text { problems in his/her job position, or other } \\
\text { areas outside it. }\end{array}$ & & & & & \\
\hline $\begin{array}{l}\text { 5. Is interested in learning and continuing to } \\
\text { receive training on a voluntary basis. }\end{array}$ & & & & & \\
\hline $\begin{array}{l}\text { 6. Suggests new ideas to improve how the job } \\
\text { tasks are done. }\end{array}$ & & & & & \\
\hline $\begin{array}{l}\text { 7. Usually expresses the desire to retire or quit } \\
\text { the company. }\end{array}$ & & & & & \\
\hline $\begin{array}{l}\text { 8. Acquires new knowledge faster than his/her } \\
\text { colleagues. }\end{array}$ & & & & & \\
\hline
\end{tabular}




\section{Appendix B}

Once you have completed a survey for each employee being evaluated, place the number assigned to them in the box on the table below that best defines their potential (what they can and/or are willing to achieve) and their performance (currently).

\begin{tabular}{|l|l|l|l|l|}
\hline \multirow{4}{*}{ Potential } & High & & & \\
\cline { 2 - 5 } & Medium & & & \\
\cline { 2 - 5 } & Low & Low & Medium & High \\
\cline { 2 - 5 } & & \multicolumn{3}{|c|}{ Performance } \\
\cline { 2 - 5 } & & \multicolumn{3}{|c|}{} \\
\hline
\end{tabular}

Intangible Capital, 2020 (www.intangiblecapital.org)

\section{(c) (1) \$}

Article's contents are provided on an Attribution-Non Commercial 4.0 Creative commons International License. Readers are allowed to copy, distribute and communicate article's contents, provided the author's and Intangible Capital's names are included. It must not be used for commercial purposes. To see the complete license contents, please visit https://creativecommons.org/licenses/by-nc/4.0/. 